\title{
PELATIHAN PENGENALAN AKUNTANSI BAGI UMKM DI KECAMATAN CIPAYUNG JAKARTA TIMUR
}

\author{
Lidya Primta Surbakti ${ }^{1}$, Agus Maulana ${ }^{2}$, Aniek Wijayanti ${ }^{3}$ \\ 1,2,3Program Studi Akuntansi, Fakultas Ekonomi dan Bisnis, Universitas Pembangunan Nasional \\ Veteran Jakarta \\ E-mail Masing-masing penulis: lidyaprimtasurbakti@gmail.com ${ }^{1}$, agus.maulana@upnvi.ac.id² \\ anieksatu@gmail.com ${ }^{3}$ \\ Penulis untuk Korespondensi/E-mail: agus.maulana@upnvj.ac.id
}

\begin{abstract}
Abstrak
Tujuan kegiatan pengabdian kepada masyarakat ini bertujuan untuk memberikan pelatihan kepada pelaku UMKM untuk dapat mengenal bagaimana pencatatan Akuntansi usaha mereka. Dengan pengetahuan akuntansi tersebut para pelaku UMKM dapat membuat laporan keuangan usaha mereka. Dengan informasi yang tersaji dalam laporan keuangan diharapkan para pelaku UMKM bisa lebih memahami berapa biaya yang harus mereka keluarkan dan berapa laba kotor dalam usaha mereka sehingga dapat mengatur dan memelihara going concern dari usaha mereka dan dapat bertahan di masa pandemi ini. Kegiatan pelatihan dilaksanakan di kantor kecamatan Cipayung Jakarta Timur. Adapun pesertanya merupakan para pelaku usaha UMKM yang tergabung dalam komunitas Jakpreneur Kecamatan Jakarta Timur. Pelatihan ini melibatkan dosen bidang akuntansi dari UPN Veteran Jakarta dan dibantu juga oleh para mahasiswa.
\end{abstract}

Kata Kunci : Pelatihan Akuntansi, UMKM, Kecamatan Cipayung, Jakarta Timur

\begin{abstract}
The purpose of this community service activity is to provide training to MSME actors to be able to recognize how to record their business accounting. With this accounting knowledge, MSME actors can make financial reports of their businesses. With the information presented in the financial statements, it is hoped that MSME actors can better understand how much they have to spend and how much gross profit is in their business so that they can manage and maintain the going concern of their business and can survive this pandemic. The training activities were carried out at the Cipayung sub-district office, East Jakarta. The participants are MSME business actors who are members of the Jakpreneur community, East Jakarta District. This training involved accounting lecturers from UPN Veteran Jakarta and was also assisted by students.
\end{abstract}

Keywords : Accounting Training, MSMEs, Cipayung District, East Jakarta.

\section{PENDAHULUAN}

Usaha Mikro Kecil dan Menengah (UMKM) merupakan salah satu penggerak ekonomi di masyarakat. Berdasarkan data Badan Pusat Statistik (BPS), jumlah UMKM di Indonesia mencapai 56,5 juta. Jika dirata-rata maka satu unit UMKM memiliki dua pekerja. Karena jumlah orang yang bekerja pada
UMKM banyak, tak aneh jika jumlah UMKM sebagai unit usaha juga banyak. Sayangnya, produktifitas UMKM tidak linier dengan jumlah usaha dan pekerjanya.

Secara umum permasalahan yang dihadapi oleh UMKM adalah kurangnya permodalan dan akses lembaga keuangan. Ternyata, dari 56,5 juta UMKM, yang mendapatkan kredit sekitar 15,6 juta unit atau 
hanya 27,6 persen. Artinya, sekitar 40 juta UMKM, yang hampir semuanya tergolong usaha mikro, tidak pernah mendapatkan dukungan permodalan dari bank. Merekamereka yang tidak pernah mendapatkan kredit dari bank itu antara lain sebagian besar dari para petani, sebagian besar dari nelayan, tukang ojek, buruh bangunan, penjual warteg dan semacamnya. Mereka umumnya berusaha dengan memutar uang sendiri, uang pinjaman dari tetangga dan saudara, atau meminjam dari tengkulak dengan bunga mencekik leher.

Kesulitan akses permodalan ini disebabkan karena tidak adanya pelaporan keuangan yang memadai sebagai salah satu syarat mendapatkan pendanaan. Pelaku UMKM hanya berfokus melaksanakan usaha untuk memenuhi kebutuhan hidupnya tanpa memperhatikan masalah perijinan dan administrasi. Pemerintah dan Otoritas Jasa Keuangan (OJK) sebenarnya cukup gencar melakukan sosialisasi penyaluran kredit mikro dalam bentuk Kredit Usaha Rakyat (KUR). OJK, bersama bank-bank juga gencar mempromosikan program Laku Pandai atau Layanan Keuangan Tanpa Kantor dalam Rangka Keuangan Inklusif. Program ini bertujuan menyediakan layanan perbankan atau layanan keuangan lainnya melalui kerja sama dengan pihak lain (agen bank), dan didukung dengan penggunaan sarana teknologi informasi.

Pengetahuan dan keterampilan dalam penyusunan laporan keuangan selama masa pandemi ini mutlak diperlukan sebagai salah satu syarat mendapatkan akses pendanaan tersebut bagi UMKM. Pengembangan teknologi dan aplikasi digital memberikan banyak pilihan aplikasi dalam pengelolaan keuangan untuk pelaku UMKM.

Mitra kami yaitu UMKM di kecamatan cipayung memiliki permasalahan dan kesulitan dalam melakukan pencatatan keuangan dari usaha mereka, selain itu masih sedikit yang memahami pentingnya pencatatan keuangan agar dapat menyusun strategi dan mengevaluasi kinerja usahanya. Selain itu, tidak adanya laporan keuangan dari Mitra UMKM juga menyebabkan mereka kesuliatan untuk mengajukan pinjaman modal kredit ke bank, karena laporan keuangan biasanya termasuk dalam persyaratan pengajuan kredit pinjaman modal.
Tujuan dari kegiatan ini adalah untuk membantu para UMKM di Kecamatan Cipayung untuk memahami lebih jauh ap aitu pencatatan akuntansi, apa pentingnya melakukan pencatatan akuntansi, dan bagaimana menerapkan pencatatan yang efektif dan efisien. Dengan kegiatan ini, diharapkan UMKM dapat termotivasi membuat pencatatan keuangan, bahkan dapat membuat laporan keuangan untuk dapat digunakan untuk mengajukan kredit, dan untuk mengevaluasi kinerja usahanya.

Target luaran dari kegiatan ini adalah dapat terbit di jurnal ISSN atau prosiding nasional ber ISSN. Sehingga kegiatan ini dapat memberikan input bagi para stakeholder, dan juga menambah literasi dalam bidang pencatatan keuangan di sektor UMKM.

\section{METODE}

Metode pelaksanaan yang digunakan dalam kegiatan ini adalah ceramah klasikal, diskusi tanya jawab dengan para peserta, serta tutorial praktik pembuatan laporan keuangan dan penentuan harga pokok penjualan. Adapun materi inti yang disampaikan adalah sebagai berikut:

1. Pengertian akuntansi secara umum

2. Tujuan pembuatan laporan keuangan

3. Kendala dan Solusi dalam penyusunan laporan keuangan di pelaku UMKM

4. Pencatatan Akuntansi untuk UMKM

5. Laporan Keuangan

6. Penentuan Harga Pokok Penjualan (Biaya Bahan Baku, Biaya Tenaga Kerja, dan Biaya Tidak Langsung)

\section{HASIL DAN PEMBAHASAN}

\subsection{Persiapan Kegiatan}

Sebelum melaksanakan kegiatan pengabdian masyarakat ini kami terlebih dahulu melakukan beberapa tahapan persiapan, diantaranya yaitu:

1. Penjajakan dengan Mitra: pada tahapan ini kami melakukan observasi dan kordinasi dengan mitra dalam hal ini adalah pimpinan di Kecataman Jakarta Timur. Dari penjakakan ini kami mendapatkan kontak bapak Kasatpel KUKMP 
Kecamatan Cipayung. Dengan Kasatpel KUMKP ini kami mendapatkan masukan untuk menganalisis permasalahan yang dihadapi oleh pelaku UMKM di kecamatan Jakarta Timur

2. Pengajuan Perizinan: Setelah terjadi kesepakatan antara kasatpel dengan tim pelaksana pengabdian masyarakat, maka kami mulai mengajukan izin kegiatan kepada Kantor Kecamatan Jakarta Timur dan Fakultas Ekonomi dan Bisnis UPN Veteran Jakarta

3. Sosialisasi Kegiatan: Setelah mendapatakan izin kegiatan, kami mulai melakukan sosialisasi dengan menyebarkan brosur. Brosur ini dibantu disebarkan juga oleh petugas di kantor kecamatan kepada para Pelaku UMKM.

4. Pendaftaran Peserta: Kami menjaring peserta dan meminta mereka untuk mengisi google form pendaftaran peserta. Setelah peserta mendaftar, mereka akan diarahakan untuk bergabung di group Whatsapp untuk memudahkan kordinasi.

\subsection{Jadwal Pelaksanaan Kegiatan}

Kegiatan pengabdian kepada masyarakat ini dilaksanakan pada Hari Kamis, 10 Juni 2021 bertempat di Aula Kantor Kecamatan Jakarta Timur. Kegiatan dibukan pada pukul 08.00 dan berakhir pukul 15.00.

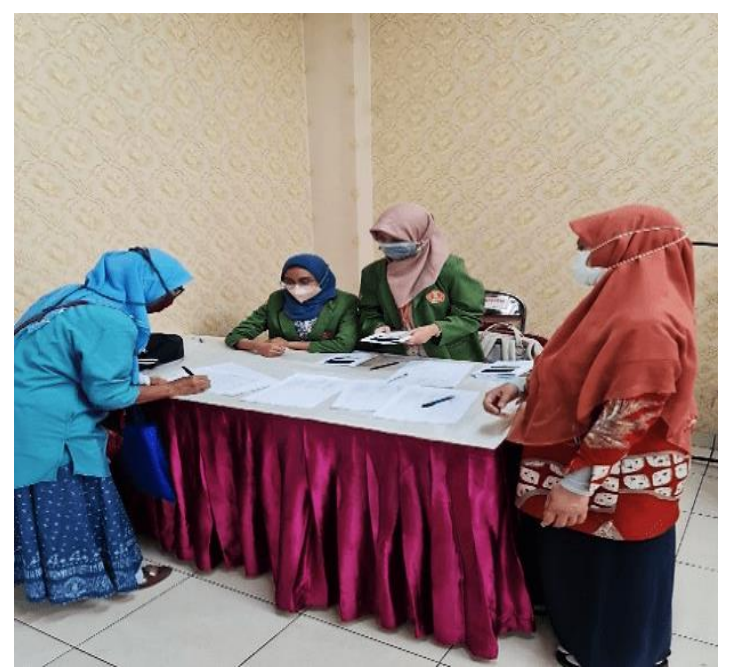

Gambar 1. Proses Pendaftaran Peserta Sumber: Data Abdimas, 2021

Adapun peserta yang hadir sebanyak 18 orang. Terdiri dari pelaku UMKM yang tergabung dalam komunitas Jakpreneur.

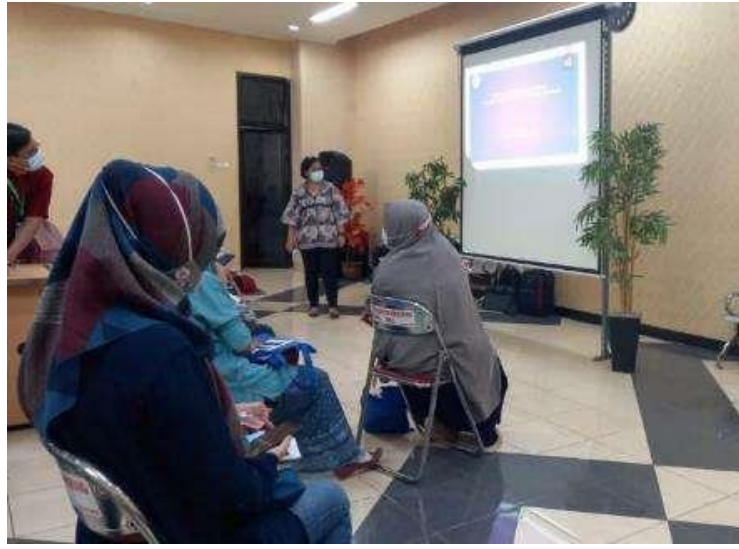

Gambar 2. Pelaksanaan Pelatihan Sumber: Data Abdimas, 2021

Acara dibuka oleh Kasatpel KUKMP Kecamatan Cipayung yaitu Fajar Sugiharto. Kemudian acara dilanjutkan dengan Materi yang disampaikan oleh Lidya Primta Surbakti, SE, MSi, Ak, CA, Ph.D.

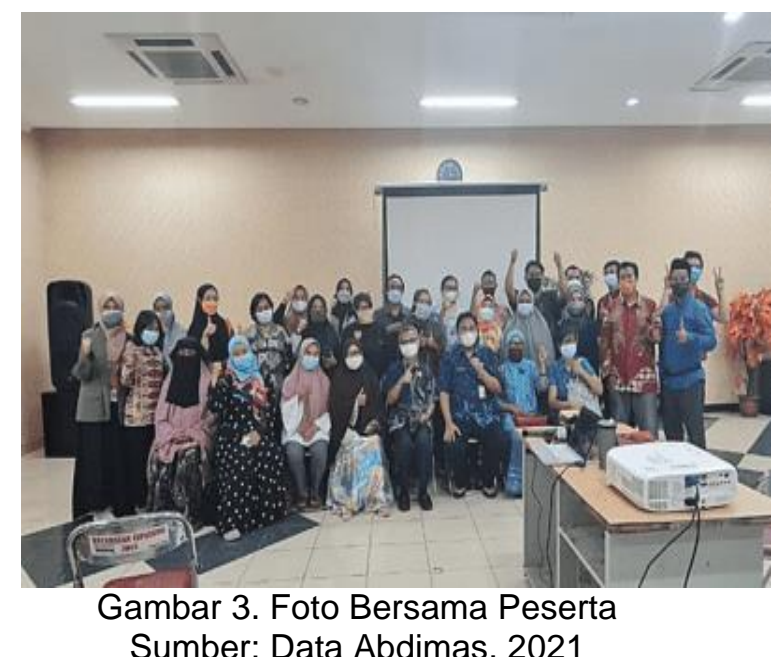

Acara diakhir dan ditutup dengan foto bersama seluruh peserta, tim dosen pengabdian masyarakat, jajaran KUMKM kecamatan Jakarta Timur, dan perwakilan mahasiswa Fakultas Ekonomi dan Bisnis UPN Veteran Jakarta.

\subsection{Materi Pelatihan}

Permasalahan dari pelaku UMKM yaitu mereka tidak mempunyai pengetahuan tentang bagaimana akuntansi usaha mereka. Selama masa pandemi covi19 ini UMKM merasa lebih kesulitan dalam bersaing karena pennjualan tidak dapat dilakukan secara normal tetapi harus online.

Beberapa UMKM hanya membuat laporan uang masuk dan keluar saja sedangkan itu tidak bisa mencerminkan 
keadaan keuangan usaha mereka. Karena laporan mereka hanya sebatas laporan sederhana saja dan belum memahami bagaimana cara untuk membuat laporan keuangan untuk usaha yang mereka jalankan.

Untuk itu, dalam rangka mengembangkan UMKM dan menciptakan UMKM yang feasible, accountable, dan profitable maka sangat dibutuhkan partisipasi pemerintah dan masyarakat dalam mendorong diterapkannya praktik akuntansi di UMKM secara tepat, implementatif dan berkelanjutan (Nedsal dkk 2013). Menurut Teti rahmawati dan Okatviani (2017) hasil penelitian mereka dengan UKM di Kuningan Jawa Barat menyatakan perlunya sosialisasi dan pelatihan pelaporan keuangan sesuai standar ETAP.

Penyajian Laporan keuangan menurut Standar Akuntansi Keuangan Entitas Mikro Kecil Menengah (SAK EMKM) 2018 di Bab 3, laporan keuangan minimum terdiri dari laporan posisi keuangan pada akhir periode, laporan laba rugi selama periode dan catatan atas laporan keuangan yang berisi tambahan dan rician pos pos tertentu yang relevan. Penyajian Laporan keuangan sangat sederhana diminta oleh SAK EMKM untuk memudahkan bagi pelaku usaha UMKM untuk membuatnya.

Adapun Materi yang disampaikan selama pelatihan diantaranya adalah sebagai berikut (1) Pengertian akuntansi secara umum, (2) Tujuan pembuatan laporan keuangan, (3) Kendala dan Solusi dalam penyusunan laporan keuangan di pelaku UMKM, (4) Pencatatan Akuntansi untuk UMKM, (5) Laporan Keuangan, (6) Penentuan Harga Pokok Penjualan (Biaya Bahan Baku, Biaya Tenaga Kerja, dan Biaya Tidak Langsung).

Pada sesi materi, kami mensosialisasikan betapa pentingnya pembuatan laporan keuangan dasar, kemudian diberikan pelatihan dan pengenalan akuntansi Bagi UMKM. Dengan demikian dalam usaha UMKM terlihat berapa banya keuntungan yang tercermin dari laporan laba rugi. Dengan demikian kemandirian dan keberlangsungan usaha para UKM semakin meningkat.

\subsection{Indikator Keberhasilan Kegiatan}

Tujuan dari kegiatan ini adalah untuk memberikan pelatihan pencatatan akuntansi keuangan bagi pelaku UMKM di kecamatan Jakarta Preneur. Dengan memehami dan mampu membuat informasi laporan keuangan, para pelaku UMKM bisa mengevaluasi kegiatan usahanya. Selain itu mereka diharapkan bisa mengambil tindakan dari informasi yang tersedia dalam laporan keuangan untuk menjadikan usahanya terus berkembang dan berkelanjutan.

Tahap evaluasi ini dilakukan melalui beberapa tahap. Pertama, kami melakukan indentifikasi awal melalui kuesioner dan diskusi dengan para pelaku UMKM terkait kebiasaan mereka dalam melakukan pencatatan keuangan. Kami pengabdi setelah membagikan kuesioner, hasil kuesioner menunjukkan sebagian besar UMKM Cipayung belum membuat laporan keuangan, hanya membuat catatan pengeluaran dan pemasukan. Sehingga kami memberikan pengabdian masyarakat kami kepada UMKM di Cipayung

Kedua, setelah melakukan pemberian materi, kami menyebarkan kuesioner untuk melihat tanggapan dari peserta setelah mengikuti pelatihan. Ketiga, kami melakukan pendampingan dengan membuka group whatsapp dengan peserta agar peserta bisa berkonsultasi dengan para dosen untuk dapat mengimplementasikan materi yang diperoleh dari pelatihan.

\section{KESIMPULAN}

\section{Kesimpulan \\ Kegiatan pengabdian kepada} masyarakat dilaksanakan di Kecamatan Cipayung Jakarta Timur dilaksanakan dibulan Juni 2021, hasil kegiatan ini dapat disimpulkan sebagai berikut :

1. Peserta UMKM Cipayung yang mengikuti kegiatan Pengenalan Akuntansi Bagi UMKM sangat senang dan antusias dalam mengikuti setiap yang diajarkan dari awal sampai akhir.

2. Peserta UMKM Cipayung yang mengikuti sekitar 18 UMKM yang bergerak di berbagai bidang usaha dari kuliner, produksi, jasa dan lainnya.

3. Peserta UMKM Cipayung mengikuti pelatihan dan pendampingan pengenalan akuntansi Bagi UMKM sampai perhitungan laba rugi sehingga UMKM dapat mengetahui berapa berapa laba yang dihasilkan.

4. Tujuan dari kegiatan pengabdian ini tercapai peserta yaitu peserta UMKM 
Cipayung dapat memahami laporan keuangan bagi UMKM Kecamatan Cipayung Jakarta Timur.
Peserta UMKM yang mengikuti masih sedikit harus ditingkatkan karena keterbatasan waktu dan tempat serta keterbatasan dalam pelaksanaan.

\section{Saran}

\section{Ucapan Terimakasih}

Segenap Tim pelaksana kegiatan Pengabdian Kepada Masyarakat Pelatihan Pengenalan Akuntansi Bagi UMKM di Kecamatan Cipayung Jakarta Timur mengucapkan terimakasih kepada seluruh pihak yang mendukung terlaksananya kegiatan ini. Khususnya kepada Dekan Fakultas Ekonomi dan Bisnis Universitas Pembangunan Nasional Veteran Jakarta, Ibu Dr. Dianwicaksih Arieftiara, S.E., Ak., M.Ak., CA, juga kepada Ketua LPPM yakni Ibu Sri Lestari Wahyuningroem, MA., Ph.D. Ucapan terimakasih dan apresiasi juga kepada seluruh jajaran Kantor Kecamatan Cipayung yang telah berkenan menerima dan menfasilitasi kegiatan ini sehingga dapat terlaksana dengan baik. Khususnya kami sampaikan terimakasih kepada Bapak Fajar Sugiharto Kasatpel KUKMP Kecamatan Cipayung yang telah mendampingi kami selama melaksanakan kegiatan pengabdian kepada masyarakat ini.

\section{DAFTAR PUSTAKA}

Ikatan akuntan Indonesia. (2018). Standar Akuntansi Keuangan, Entitas Mikro, kecil dan Menengah, Jakarta.

Dekati Target, 7,2 Juta UMKM Sudah Go-Online - Katadata News. (2018, September 28). Diambil 12 Februari 2019, dari https://katadata.co.id/berita/2018/09/28/dekati-target-72-juta-umkmsudah-go-online

Nedsal Sixpria, Titi Suhartati, dan Sabar Warsini. (2013). Evaluasi Implementasi Standar Akuntansi Entitas Tanpa Akuntabilitas Publik (ETAP) dan Penyusunan Laporan Keuangan Auditan pada Usaha Mikro, Kecil dan Menengah (UMKM), Jurnal Ekonomi Dan Bisnis, Vol 12, No. 1, Juni 2013: 55 - 64

Rizki Rudiantoro dan Sylvia Veronica Siregar. (2012). Kualitas Laporan Keuangan UMKM serta Prospek Implementasi SAK ETAP, Jurnal Akuntansi dan Keuangan Indonesia Volume 9 No. 1, Juni 2012

Sri Mulyani. (2014). Faktor-Faktor Yang Mempengaruhi Kualitas Laporan Keuangan Pada UMKM di Kabupaten Kudus, JDEB Vol 11 No 2 Oktober 2014 hal 137

Teti Rahmawati dan Oktaviani Rita Puspasari. (2017). Implementasi SAK ETAP dan Kualitas laporan keuangan UMKM terkait akses modal Perbankan. Jurnal Kajian Akuntansi Vol 1, (1) 49-62 